\title{
EKSISTENSI BATIK ENCIM DALAM ARENA PRODUKSI KULTURAL DI PEKALONGAN
}

\author{
Tri Wulandari
}

\author{
Jurusan Kriya Fakultas Seni Rupa \\ Institut Seni Indonesia Yogyakarta \\ Jl. Parangtritis Km 6.5 Sewon Bantul, Kabupaten Bantul, Yogyakarta, Kode Pos 55001 \\ Daerah Istimewa Yogyakarta, Indonesia \\ Email: tri.wulandari@isi.ac.id
}

\begin{abstract}
Abstrak
Kajian ini bertujuan untuk menjelaskan kekuatan eksistensi batik Encim dalam arena produksi kultural mencakup arena produksi terbatas dan arena produksi skala besar. Teori arena produksi kultural oleh Pierre Bourdieu membantu dalam kajian ini khususnya meliputi: 1) aspek material maupun simbolis dari produksi karya-karya kultural, 2) peran mediator yang mempunyai andil dalam pemaknaan karya. Metode penelitian yang digunakan yaitu penelitian kualitatif bersifat deskriptif dan metode pengambilan data melalui observasi, dokumen, wawancara, dan triangulasi. Metode analisis meliputi reduksi data, penyajian data, dan verifikasi data. Hasil kajian ini menjelaskan bahwa eksistensi batik Encim dalam arena produksi terbatas diperkuat dengan adanya konsistensi pengusaha dan seniman batik dari Cina Peranakan dengan menjaga kualitas batik Encim baik dari aspek keindahan visual, teknis pembuatannya, dan fungsi kegunaanya. Memasuki arena produksi skala besar, maka keunggulan kualitas tersebut mengalami penyerderhanaan, karena mengikuti permintaan selera pasar batik Encim. Oleh karena itu, para pengusaha industri batik di Pekalongan mereproduksi batik Encim dengan segala kreativitasnya, sehingga berdampak pada lahir inovasi bentuk produk-produk industri kreatif yang beraneka ragam seperti produk batik Encim tulis, cap, sablon malam, maupun printing. Eksistensi batik Encim dipengaruhi adanya modal ekonomi, modal budaya, modal sosial, dan modal simbolik yang digunakna sebagai kekuatan untuk bertahan dalam persaingan usaha batik.
\end{abstract}

Kata Kunci: eksistensi, batik encim, produksi kultural.

\begin{abstract}
This study aims to explain the strength of Encim batik existence in cultural production arenas including limited-production arenas and large-scale production arenas. The theory of the cultural production arena by Pierre Bourdieu helped in this study in particular, include: 1) material and symbolic aspects of the production of cultural works, 2) the role of mediators who have a role in the use of works. The research method used is qualitative research is descriptive and the method of data retrieval through observation, documents, interviews, and triangulation. Analysis methods include data reduction, data presentation, and data verification. The results of this study explain that the existence of Encim batik in the production-limited arena is strengthened by the consistency of entrepreneurs and batik artists from Peranakan China by maintaining the quality of Encim batik both in terms of visual beauty, technical manufacturing, and usefulness functions. Entering the large-scale production arena, the excellenge of quality are simplified, because it follows the demand of the Encim batik market tastes. Therefore, batik industry entrepreneurs in Pekalongan reproduce Encim batik with all its creativity, so that it has an impact on the birth of innovative forms of creative industry products such as batik products Encim write, stamp, night screen printing, and printing. The of Encim batik is influenced by economic capital, cultural capital, social capital, and symbolic capital used as a force to survive in batik business competition.
\end{abstract}

Keywords: existence, batik encim, cultural production.

\section{PENDAHULUAN}

Batik merupakan mahakarya warisan nenek moyang bangsa Indonesia yang telah ditetapkan oleh UNESCO (United Nations Educational, Scientific, and Cultural Organization) sebagai salah satu warisan budaya dunia. Batik Indonesia dengan keseluruhan teknik, teknologi, dan motif hiasnya ditetapkan sebagai warisan kemanusiaan untuk budaya lisan dan non-bendawi (Master of the Oral and Intangible Cultural Heritage of Humanity). Batik telah ditetapkan menjadi warisan budaya dunia ketiga, etelah wayang dan keris yang masuk dalam Intangible Heritage of Humanity UNESCO. Perkembangan batik Indonesia di berbagai daerah diklasifikasikan dalam dua wilayah batik yakni: 
batik pedalaman dan batik pesisir. Salah satu batik pesisir terbesar di pulau Jawa berpusat di Pekalongan. Pekalongan adalah suatu daerah yang terletak di wilayah pantai utara Jawa dan menjadi pusat utama perdagangan. Pekalongan sebagai kota batik, perjalanan sejarahnya tidak lepas dari pengaruh budaya Cina, Eropa, dan Arab. Kedatangan bangsa Cina ke Pekalongan sebagai pendatang yang melakukan perdagangan, serta menjalin hubungan dengan orangorang lokal dan menikahinya, sehingga keturunannya disebut sebagai Cina Peranakan.

Masyarakat pendukung masyarakat yang multi-etnik memiliki latar belakang budaya seperti: Cina, Eropa, Arab, serta penduduk asli atau pribumi, mempengaruhi perkembangan batik Pekalongan. Berdasarkan dari gaya, selera, ragam hias, dan tata warnanya, batik Pekalongan dikelompokkan menjadi tiga kategori, yakni: 1) Batik Encim, 2) Batik yang berselera Eropa atau Belanda, dan 3) Batik rakyat atau batik yang berselerakan pribumi (Djomena, 1990: 62).

Salah satu batik Encim yang berkembang di Pekalongan adalah batik Encim. Sentra produksi batik Encim terletak di desa Kedungwuni, kecamatan Kedungwuni, kabupaten Pekalongan adalah salah satu kabupaten yang berada di arah selatan kota Pekalongan, serta dikenal sebagai daerah pencipta batik terbaik dari kelompok Tionghoa secara turun temurun dari generasi sebelumnya. Hingga kini, jumlah kelompoknya telah berangsur-angsur menurun, namun beberapa di antaranya masih tetap eksis dan dijalankan oleh generasi ketiga seperti: Oey Soe Tjoen, Liem Ping Wie, The Tie Tset, dan lain sebagainya.

Dinamika masyarakat Pekalongan dalam memproduksi dan mereproduksi batik dipengaruhi oleh faktor lingkungannya dan selera pasar yang dapat diterima dan dikomodifikasikan oleh kelompok masyarakat Pekalongan. Masyarakat Pekalongan memiliki sikap kecenderungan terbuka terhadap perubahan yang ada, mencakup berbagai bentuk, selera, dan trend yang berkembang saat ini. Dalam konteks arena produksi kultural perubahan bentuk, selera, dan trend saling mempengaruhi dan meniru satu sama lain, sehingga keberlangsungan dan eksistensiya dalam arena produksi kultural tetap ada dan diakui.

Bertolak dari permasalahan tersebut, maka penulis membatasi pokok permasalahan berkenaan dengan fenomena kekuatan eksistensi batik Encim dalam arena produksi kultural. Oleh karena itu pemikiran kritis yang diajukan dalam kajian ini yaitu: Bagaimana kekuatan eksistensi batik Encim dalam arena produksi kultural baik di arena produksi terbatas dan arena produksi skala besar?

\section{KAJIAN TEORI}

\section{Teori Sosial Budaya}

Dalam mengkaji produksi dan reproduksi motif batik Encim maka digunakan teori arena produksi kultural yang diungkapkan oleh Pierre Bourdieu seorang tokoh sosiologi budaya. Bourdieu memaparkan arena produksi kultural mencakup: 1) aspek material maupun simbolis dari produksi karya-karya kultural, 2) penyingkapan berbagai mediator yang mempunyai andil dalam pemaknaan karya dan upaya mempertahankan semesta kepercayaan yang tak lain arena kultural (Bourdieu, 2015: xliii).

Perangkat konseptual Bourdieu mengenalkzan pemahaman tentang habitus dan ranah (field). Konsepkonsep penting lainnya, seperti kekuasaan simbolik, strategi, dan perjuangan simbolik dan material, serta konsep beragam modal ekonomi, budaya dan simbolik (Bourdieu, 2009: 5). Selanjutnya dapat dipahami bahwa perangkat konseptual Bourdieu terdiri dari habitus, ranah, dan modal. Keberadaan habitus dan ranah ditopang dengan berbagai macam modal seperti modal materi atau ekonomi, modal budaya, maupun modal simbolik.

Struktur arena produksi kultural didasarkan pada dua oposisi yaitu oposisi antara sub arena produksi terbatas dan sub arena produksi skala besar, yaitu antara dua ekonomi, dua skala waktu, dua audien, yang terus menerus memproduksi dan mereproduksi eksistensi negatif sub arena produksi terbatas dan oposisi mendasarnya dengan tatanan ekonomi borjouis (Bourdieu, 2009: 38). Pada dasarnya Bourdieu mempertentangkan dua oposisi dalam arena produksi kultural yaitu arena produksi terbatas dan arena produksi skala besar. Arena produksi terbatas digunakan untuk mengungkap praktik produksi motif batik Encim dalam skala produksi terbatas oleh pengusaha batik Cina Peranakan, sedangkan arena produksi skala besar digunakan untuk mengungkap praktik produksi dan reproduksi motif batik Encim dalam skala produksi besar atau produksi massal oleh pengusaha industri batik di Pekalongan.

\section{Teori Batik}

Defini batik menurut Dewan Standarisasi Tekstil Indonesia (DSTI) dan Standar Industri Indonesia (SII), batik merupakan kain tekstil hasil dari proses pewarnaan, pencelupan rintangan menurut corak khas ciri batik Indonesia, serta menggunakan lilin batik 
sebagai zat perintangan dalam proses pewarnaan (Susanto, 1984: 4).

Batik yaitu kain yang ragam hiasnya ditulis dengan menggunakan malam sebagai perintangan warna, sehingga zat warna tidak dapat masuk ke dalam bagian kain yang tertutup malam saatpencelupan warna. Dalam proses membubuhkan malam di atas kain, maka digunakan canting sebagai alat menuliskan lilin malam. Bentuk kecil seperti mangkuk berujung pipa kecil berbahan tembaga, yang diberi gagang pegangan dari bahan kayu atau bambu (Ishwara et al., 2011: 23).

Menurut N. Tirta Amidjaya, esensi batik merupakan karya seni yang banyak menerapkan unsur menggambar motif ornamen di kain dengan menggunakan teknik tutup celup. Hal ini maksudnya menorehkan lilin malam pada kain yang berisikan motif-motif ornamentif dengan alat bantu canting. Pada zaman dulu karya seni yang memiliki banyak ornamen penghias dapat disebut dengan karya seni tulis karena proses membuat batik dibuat hampir mirip dengan teknik menulis atau menyungging (Amidjaja, 1966: 3). Berdasarkan pengertian tersebut, dapat disimpulkan bahwa batik sebagai karya seni berkaitan erat dengan proses, teknik, dan keindahan. Membatik merupakan proses memberikan corak motif di atas kain dengan menggunakan alat bantu berupa canting untuk menorehkan malam.

\section{METODE PENELITIAN}

Penelitian ini bersifat kualitatif, maka data yang diperoleh adalah data kualitatif. Oleh sebab itu, penelitian ini menggunakan pendekatan kualitatif yang bersifat deskriptif. Metode pengambilan data melalui: a). Observasi: Metode observasi ini dimanfaatkan untuk menggali data dan mendokumentasikan kegiatan produksi batik Encim di kalangan pengusaha batik Cina Peranakan dan pengusaha batik industri batik Encim, b). Wawancara: Wawancara langsung dilakukan kepada nara sumber utama seperti: pengusaha batik Cina Peranakan, pengusaha batik industri di Pekalongan, serta para profesional ahli bidang batik, c). Dokumen adalah data pelengkap yang mendukung metode observasi dan wawancara dalam penelitian kualitatif. Metode ini untuk menggali dan menelusuri sumber tertulis baik dari buku, jurnal, ensiklopedi, kamus, arsip, katalog, dan gambar yang berkaitan dengan batik Encim, dan d). Triangulasi: Metode ini digunakan untuk mengumpulkan data sekaligus memvalidasi data dengan berbagai teknik pengumpulan data dan berbagai sumber data yang telah didapatkan. Selanjutnya data yang diperoleh kemudian dicek validitas dan keakuratannya.
Gorga : Jurnal Seni Rupa

Volume 10 Nomor 01 Januari-Juni 2021

p-ISSN: 2301-5942 | e-ISSN: 2580-2380

Metode analisis data adalah serangkaian proses penyusunan data, pengolahan data, dan interaksi data yang diperoleh dari pengamatan di lapangan dengan cara observasi, wawancara, dokumentasi, dan triangulasi. Selanjutnya peneliti dapat memberikan sajian data dan mengambil kesimpulanm utama. Analisis data penelitian ini dijelaskan secara diskriptif kualitatif. Miles dan Hubermus telah menjelaskan terdapat tiga unsur penting dalam proses analisis penelitian kualitatif yaitu: reduksi data, penyajian data, dan verifikasi data (Miles, 1992: 18).

\section{HASIL DAN PEMBAHASAN \\ 1.Hasil}

Batik Encim merupakan objek kultural yang berupa artefak, sehingga batik Encim dinilai sebagai benda seni bernilai estetis tinggi, nilai teknis yang rumit, dan nilai simbolis sebagai penanda status sosial masyarakat pada masanya. Memasuki era ekonomi kreatif yang mengusung konsep industri kreatif, maka penciptaan produk-produk kreatif diharapkan mampu memenuhi kebutuhan pasar. Salah satunya adalah batik Encim, selain sebagai benda seni yang memiliki nilai estetis tinggi, tetapi di sisi lain juga sebagai produk industri. Kini beberapa kalangan pengusaha industri batik memposisikannya sebagai produk industri dengan cara memproduksi dan mereproduksinya dalam jumlah skala besar. Dalam arena industri kreatif, sebuah produk diciptakan dengan mengutamakan aspek nilai ekonomi didukung dengan aspek fungsi produk itu sendiri.

Batik sebagai produk budaya, kini telah menjadi bagian ekonomi kreatif di Indonesia. Ekonomi kreatif telah memberikan ruang khusus batik untuk memasuki ke ranah yang lebih luas seperti bidang usaha retail, busana, maupun desain industri. Batik Encim telah menjadi produk budaya masyarakat Pekalongan yang tidak hanya terwakili oleh kalangan pengusaha batik Cina Peranakan sebagai perwakilan sub arena produksi terbatas dalam kekuatan produksi kultural. Namun disisi lain, keberadaan batik Encim juga didukung oleh kalangan pengusaha industri batik di Pekalongan yang mewakili sub arena produksi skala besar. Pengusaha industri batik telah memproduksi dan mereproduksi batik Encim menjadi produk industri. Fenomena ini dapat dijelaskan melalui pembahasan arena produksi kultural yang terbagi menjadi sub arena produksi terbatas dan sub arena produksi skala besar.

\section{Pembahasan}

\section{1). Sub Arena Produksi Terbatas}

Batik Encim sebagai ranah praktik produksi dan reproduksi produk budaya telah menunjukkan 
dinamika perubahan motifnya. Perubahan tersebut didorong dengan adanya kekuatan kreatifitas dan kekuatan ekonomi para pelaku atau produsen batik Encim. Praktik produksi dan reproduksi batik Encim secara kontinu dilakukan oleh pengusaha batik Cina Peranakan dengan kesuluruhan kekuatan daya kreativitasnya. Praktik produksi dan reproduksi seperti pembuatan ulang motif batik juga telah dilakukan dari kalangan pengusaha batik Cina Peranakan sendiri. Oey Soe Tjoen sebagai pengusaha batik Cina Peranakan tradisional menempati posisi sub arena produksi terbatas.

Pada generasi pertama, Oey Soe Tjoen mampu menuangkan kreatifitas melalui penciptaan desain motif batik Encim sekitar 82 motif batik pada produk berupa kain sarung, kain panjang, dan kain panjang pagi sore. Pada generasi kedua, Oey Kam Long banyak memproduksi dan reproduksi motif batik yang pernah diproduksi pada generasi pertama. Selain itu, Oey Kam Long telah memproduksi 10 desain motif batik dan mengembangkan beberapa bentuk isèn-isèn seperti: sulur lung-lungan. Hingga kini, memasuki generasi ketiga, Oey Kim Lian atau sering disapa dengan nama Widianti Widjaja mampu memproduksi lebih dari 50an desain motif batik. Widianti Widjaja menegaskan bahwa pada generasi ketiga telah membedakan dua jenis golongan batik berdasarkan motifnya yakni: batik klasik dan batik kreasi baru. Batik klasik merupakan batik repro dari desain motif batik generasi sebelumnya, dalam artian bahwa batik yang diproduksinya sesuai dengan desain motif batik generasi sebelumnya dan sesuai pakem batik Oey Soe Tjoen. Khusus batik kreasi baru, merupakan batik yang keluar dari pakem batik Oey Soe Tjoen. Hal tersebut menunjukkan bahwa dari kalangan Cina Peranakan khususnya generasi Oey Soe Tjoen telah menampakkan perubahan desain motif batiknya. Perubahan desain motif ini menunjukkan adanya kekuatan kreatifitas yang berkembang dari generasi pertama hingga ketiga.

Widianti Widjaja telah menegaskan bahwa kini terdapat perubahan fungsi kegunaan batik Encim, dari awalnya sebagai hantaran pernikahan telah berubah menjadi benda koleksi atau barang khusus yang digunakan pada acara tertentu. Batik Encim hasil produksi "Batik Art" milik Oey Soe Tjoen telah menjadi benda seni yang banyak dicari oleh beberapa kalangan tertentu seperti para kolektor dan pecinta batik. Pada dasarnya batik tersebut memiliki nilai estetis, teknis, dan ekonomi yang tinggi. Oleh sebab itu, produk batik Encim yang diproduksi oleh pengusaha Cina Peranakan Oey Soe Joen mampu menunjukkan sebagai benda seni yang memiliki kekuatan kreatifitas penciptanya. Daya kreativitas dapat dilihat melalui keunggulan aspek estetis, teknis pembuatannya, dan nilai ekonomi yang tinggi.

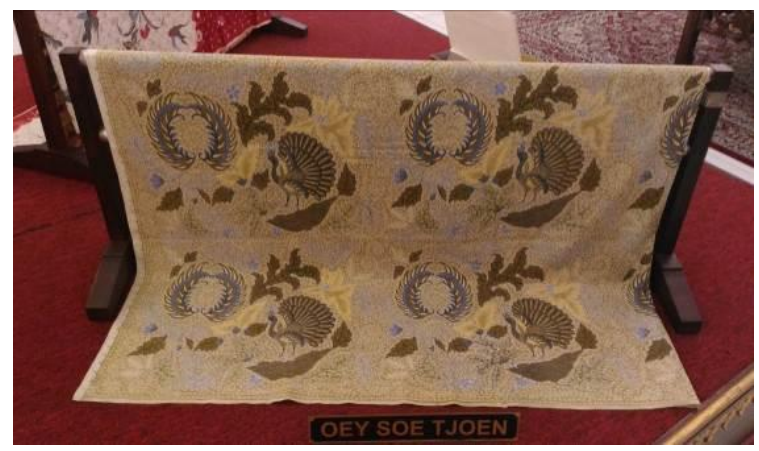

Gambar 1. Batik Oey Soe Tjoen Menjadi Koleksi Museum Batik Danar Hadi.

(Wulandari, 2017)

Eksistensi keberlangsungan produksi batik tidak bisa terlepas dari peran pembatik halusan yang semakin berkurang. Hal ini menjadi tantangan internal dalam eksistensi batik Oey Soe Tjoen. Tantangan eksternal batik Oey Soe Tjoen yaitu bermunculan pengusaha industri batik yang memiliki kreativitas dalam proses produksi batik dan telah mengembangkan banyak keteknikan. Selain itu praktik produksi dan reproduksi batik Encim dilakukan dengan cara saling tiru meniru gaya atau style motif batik Encim di kalangan pengusaha industri batik. Oleh karena itu, kalangan pengusaha industri batik ini menempati sub arena produksi skala besar.

\section{2). Sub Arena Produksi Skala Besar}

Dalam perkembangannya, seni sering memperoleh masukan dari apa yang ditemukan dalam dalam ilmu pengetahuan dan teknologi, dan sebaliknya ilmu pengetahuan dan teknologi yang tidak diperoleh seni terasa hambar dan kering. Seni tradisional berusaha mempertahankan pola dan kaidah yang ada, sedangkan seni modern dengan kreativitas selalu haus akan inovasi dan perubahan dengan kata kunci "kebaruan" (Soedarso, 2006: 134).

Fenomena yang berkembang di Pekalongan ditandai dengan adanya banyak pengusaha industri batik yang mengembangkan batik Encim dengan berbagai keteknikan batik seperti: batik tulis, batik cap, batik sablon malam dingin (hand-printing), dan batik printing (machine-printing). Keberadaan batik tersebut menjadi tantangan bagi pengusaha batik tradisional, sehingga terdapat ketimpangan antara pengusaha batik tradisional dengan pengusaha batik industri.

Pada sub arena produksi skala besar, pengusaha batik industri berperan sebagai produsen produk yang 
Gorga : Jurnal Seni Rupa

Volume 10 Nomor 01 Januari-Juni 2021

p-ISSN: 2301-5942 | e-ISSN: 2580-2380

memiliki kreatifitas tinggi dalam menciptakan produk batik. Kekuatan daya kreatif menghadirkan produk batik Encim dengan berbagai jenis batik berdasarkan teknik pembuatannya seperti: tulis, cap, sablon malam (hand-printing), hingga printing (machine-printing). Dengan adanya jenis batik yang berbeda-beda tersebut, maka berdampak pada perbedaan kualitas dan harga batik Encim.

Pertama, batik Encim dengan teknik batik tulis, kemudian penulis menyebut batik Encim tulis. Pembuatan batik Encim tulis pada kalangan industri batik sering terjadi hal tiru meniru desain yang sedang menjadi trend dan laris di pasaran. Para pengusaha industri batik tidak hanya sekedar tiru-meniru, namun juga mengembangkan desain sesuai kreasinya masingmasing. Hal tiru-meniru desain menjadi lumrah di kalangan pengusaha industri batik, karena banyak desain motif yang diciptakan tidak memiliki hak paten desain maupun hak merk produk.

Selain tiru-meniru, hal yang paling krusial adalah adanya penjiplakan desain motif dan nama merk batik. Hal ini dialami oleh Widianti Widjaja selaku produsen batik Oey Soe Tjoen. Ada beberapa oknum pengusaha industri batik yang bersaing dengan membuat produk yang sama, namun harga terjangkau lebih murah. Desain motif batik dan penggunaan nama label merk Oey Soe Tjoen sering kali dipalsukan oleh beberapa oknum pengusaha industri batik. Batik yang sama namun memiliki kualitas dan harga jual yang berbeda. Berikut ini perbandingan batik Oey Soe Tjoen yang asli dan palsu.

Tabel 1. Ciri-Ciri Batik Oey Soe Tjoen Asli dan Palsu

\begin{tabular}{|c|c|}
\hline Asli & Palsu \\
\hline $\begin{array}{l}\text { Clag Ofe Gioen } \\
\text { Kedoengwoeni lof } \\
\text { "Oey Soe Tjoen, Kedoengwoeni, } \\
\text { 104" } \\
\text { Huruf "O" versi disambung. }\end{array}$ & $\begin{array}{l}\text { Ciri: } \\
\text { 1. Penulisan nama "Oey Soe } \\
\text { Tjoen, Kedoengwoeni, 104" } \\
\text { tidak rapi dan detail. } \\
\text { 2. Pada bagian tepi dibatasi } \\
\text { dengan garis lurus yang tebal } \\
\text { dan tidak rapi. } \\
\text { 3. Arah tulisan tidak stabil. } \\
\text { 4. Penggunaan huruf "K" } \\
\text { memiliki ujung ekor garis di } \\
\text { bagian atas dan bawah. }\end{array}$ \\
\hline
\end{tabular}

1. Penulisan nama "Oey Soe

Tjoen, Kedoengwoeni, 104"

sangat rapi dan detail.

2. Pada bagian tepi dibatasi dengan isèn- isèn titik, walaupun ada beberapa nama yang tidak

3. Arah tulisan miring ke arah kanan.

4. Penggunaan huruf " $\mathrm{K}$ " memiliki ujung ekor garis di bagian bawah

5. Motif batik sesuai dengan tradisi, pakem dan pola motif batik Oey Soe Tjoen.

6. Kualitas goresan cantingan hasil batik memiliki tingkat kehalusan, kelembutan, kerumitan, dan kerapian yang tinggi.

7. Kualitas warna lebih bagus, cerah, merata, unik, dan berkarakter. batasi dengan isèn-isèn titik.

5. Motif batik telah diberikan sedikit pengembangan, namun secara kasat mata hampir menyerupai motif yang asli.

6. Kualitas goresan cantingan hasil batik hampir menyerupai tingkat kehalusan, kelembutan, dan kerumitan batik Oey Soe Tjoen.

Namun hal yang paling susah ditiru adalah gaya penulisan nama "Oey Soe Tjoen"

7. Kualitas warna hampir sama dengan batik Oey Soe Tjoen, namun ada beberapa warna yang tidak bisa dicapai atau menyamai warna asli batik Oey Soe Tjoen karena perbedaan ramuan atau campuan warna yang digunakan pada saat pewarnaan.

Penggunaan tanda tangan memberikan keuntungan berlipat ganda bagi pengusaha industri batik yang telah memproduksi dan mereproduksi batik dengan cara menambahkan atau mencantum nama label "Oey Soe Tjoen". Pemberian label nama batik dan penggunaan tanda tangan "Oey Soe Tjoen" memiliki daya kekuatan untuk menaikkan harga jual dari sebuah produk batik. Upaya produksi dan reproduksi dengan cara memalsukan batik Oey Soe Tjoen merupakan salah satu upaya pengusaha industri batik untuk mendapatkan keuntungan yang besar. Tidak semua pengusaha industri batik memproduksi dan mereproduksi dengan mencantumkan nama "Oey Soe Tjoen", namun beberapa diantaranya hanya saling tiru meniru unsur-unsur visual motif batik Oey Soe Tjoen dan mengikuti stlye atau gaya teknik membatik maupun teknik pewarnaan, kemudian dikreasikan dan dikembangkan sesuai kreatifitas masing-masing pengusaha industri batik.

Batik Oey Soe Tjoen dari generasi ke generasi sangat menjaga standar kualitas, mutu, dan tradisi membatik yang diwariskan secara turun temurun. Widianti Widjaja berupaya sebatas memperingatkan pelaku penjiplakan karya batiknya secara personal. Tidak ada upaya menuntut penggunaan hak nama "Oey Soe Tjoen", karena memang nama "Oey Soe Tjoen" belum memiliki hak patennya. Walaupun demikian, para pecinta batik, kolektor batik, pelaku batik, dan praktisi batik sebagai masyarakat pendukungnya telah mengakui bahwa batik Oey Soe Tjoen merupakan salah satu batik yang memiliki nilai estetis yang tinggi. Hal tersebut menjadi kekuatan legitimasi dan penghargaan 
khusus pada batik Oey Soe Tjoen sebagai sebuah karya seni. Selain memiliki nilai estetis tinggi juga memiliki nilai keteknikan proses pembuatannya yang bermutu, hasil warna yang lembut, kualitas hasil cantingan yang halus, dan penggambaran detail-detail motifnya yang sangat rumit.

Kedua, batik Encim dengan teknik batik disebut dengan batik Encim cap. Kalangan pengusaha industri batik cap ini memproduksi batik Encim cap dengan menyederhanakan motif dan unsur-unsur pembentuknya seperti: unsur isèn- isèn motif pada bagian daun dan bunga. Hal ini dilakukan karena banyak unsur-unsur isèn- isèn yang halus dan rumit tidak dapat dicapai dengan menggunakan teknik batik cap. Hasil batik cap ini dapat dilihat dari hasil garis klowongan kurang halus, isèn- isèn kurang lembut, tidak ada bentuk isèn- isèn yang rumit, dan ada beberapa bagian yang kurang rapi. Selain itu dapat dicermati hasil batik pada bagian depan dan belakang kain hampir sama, namun lebih jelas hasil batik pada bagian depan. Berikut ini contoh hasil batik Encim cap. Ketiga, batik Encim dengan teknik sablon malam dingin atau hand-printing, kemudian disebut dengan batik Encim sablon. Kalangan pengusaha industri batik sablon ini justru berupaya memproduksi batik Encim dengan berusaha menyamai bentuk motif dan mencapai unsur-unsur terkecil pembentuknya. Hal ini tampak dari penggunan unsur isèn- isèn motif pada bagian daun dan bunga digambarkan dengan detail isèn- isèn titiknya. Teknik batik sablon ini memiliki kelebihan dapat mencapai garis maupun titik terkecil.

Hal yang paling penting perlu dicermati hasil motif batik pada bagian depan kain tidak sama dengan pada bagian belakang kain, tidak seperti pada batik tulis dan batik cap. Walaupun teknik sablon dapat mencapai garis dan titik terkecil, namun apabila dicermati masih ada beberapa garis klowongan yang besar atau tidak rapi karena efek dari penggabungan proses produksi yang menggunakan teknik sablon lilin malam dan teknik tulis. Penggunaan warna yang digunakan sangat beraneka ragam, mulai dari warna muda (soft-color) hingga warna tua (dark-color). Teknik sablon salah satu teknik yang dapat mencapai hasil mendekati sempurna, sehingga dapat memanipulasi hasil batikan secara kasat mata. Bagi konsumen yang awam tentang pengetahuan batik, maka akan terkecoh dengan hasil batikan teknik sablon lilin malam yang hampir menyerupai hasil batik tulis maupun cap.

Keempat batik Encim dengan teknik batik printing atau machnine-printing, kemudian disebut dengan batik Encim printing. Batik printing biasanya diproduksi dengan menggunakan alat mesin print kain, sehingga kain batik yang dihasilkan dapat dicapai dalam satu kali proses printing. Batik printing tidak melalui proses pencantingan atau menorehkan lilin malam panas di atas kain, sehingga proses pewarnaan tidak menggunakan halang rintang dengan lilin malam. Salah satu fungsi lilin malam pada proses pewarnaan yaitu menghalangi atau merintangi warna agar tidak masuk pada bagian yang telah dicanting dengan lilin malam. Batik printing pada dasarnya tidak termasuk dalam kategori batik ditinjau dari aspek teknik pembuatannya, namun dapat disebut sebagai kain bermotif batik atau tekstil bermotif batik, tetapi bagi masyarakat awam yang terbatas pengetahuan sering menyebutnya sebagai batik printing.

\section{3). Modal Dalam Arena Produksi Kultural}

Dalam praktik produksi dan reproduksi batik Encim, terdapat dua oposisi yaitu oposisi kalangan pengusaha batik tradisional yang mempertahankan teknik batik tulis dengan mempertahankan kualitas proses pembuatan batik sesuai tradisi, sedangkan oposisi kalangan pengusaha industri sangat kreatif mengembangkan keteknikan dalam proses produksi batik, sehingga muncul berbagai jenis batik. Kreatifitas para proses produksi yang dilakukan mempertimbangkan penggunaan bahan baku malam maupun warna yang efisien dan percepatan proses produksi yang efektif. Proses produksi yang tidak terlalu lama, singkat, cepat, namun dapat menghasilkan produk batik dalam jumah skala besar, sehingga berdampak pada peningkatan pendapatan keuntungan. Diantara kedua oposisi tersebut salah satunya menempati posisi subordinat atau terdominasi seperti pengusaha batik Cina Peranakan sebagai pengusaha batik tradisional. Wilayah terdominasi tampak pada kondisi jumlah pengusaha batik Cina Peranakan yang sangat terbatas, proses produksi batik yang membutuhkan waktu lama, hasil jumlah produksi yang terbatas, dan harga jual yang tinggi. Hal tersebut memberikan peluang para pengusaha industri batik untuk mendominasi peran terutama dalam penciptaan produk batik Encim yang mampu bersaing di pasaran. Posisi peran dominan pengusaha industri batik ditunjukkan dengan adanya semakin banyak bermunculan pengusaha industri batik untuk memproduksi dan reproduksi batik Encim. Pengusaha industri batik mempertimbangkan proses produksi batik yang singkat, hasil jumlah produksi yang besar, dan harga jual lebih murah namun mendapatkan keuntung berlimpah.

Modal digolongkan ke dalam empat kategori yakni: modal ekonomi, budaya, sosial, dan simbolik yang 
Gorga : Jurnal Seni Rupa

Volume 10 Nomor 01 Januari-Juni 2021

p-ISSN: 2301-5942 | e-ISSN: 2580-2380

dikumpulkan dari penggabungan bentuk penghargaan atau prestise, status, otoritas kebijakan, dan pengakuan legitimasi (Fashri, 2014: 109-110). Adanya kepemilikan dan kekuatan modal sangat mendukung kekuasaan memenangkan pasar industri kreatif. Modal tidak hanya sebatas modal ekonomi saja, namun dibutuhkan modal budaya, sosial, dan simbolik.

Modal budaya juga terkait dengan kemampuan untuk menampilkan diri di depan publik dan kemampuan memiliki keahlian tertentu seperti: keahlian tertentu dari hasil pendidikan, maupun keterampilan skill tertentu, sehingga dapat menunjangkan pengusaha industri batik untuk bersaing dengan para pesaingnya.

Modal sosial dapat berupa bentuk jaringan sosial yang dimiliki pengusaha industri batik baik secara individu maupun kelompok. Kemampuan jaringan sosial mempunyai relasi dengan pihak-pihak yang memiliki kekuasaan tertentu seperti dengan pihak pemerintah, bank, agen distributor produk, media radio, televisi, jurnalisme, sosial media mulai dari webside, blog, facebook, instagram, dan lain sebagainya. Modal sosial sangat menguntungkan untuk mengakses fasilitas, kesempatan, dan peluang yang mendukung keberlangsungan usahanya. Modal sosial menjadi akses untuk memperkuat modal ekonomi dan modal budaya. Selain ketiga modal tersebut, terdapat modal simbolik yang berfungsi untuk mendukung legitimasi maupun status.

Modal simbolik merupakan kumpulan dari segala bentuk prestise, status, otoritas, dan legitemasi. Pengusaha industri batik mendapatkan modal simbolik atas kesuksesannya menjalankan bisnis batik, semakin besar keuntungan yang didapatkannya maka semakin menguatkan keberhasilan bisnisnya. Selanjutnya berdampak pada penghargaan prestise, status sebagai pengusaha industri batik yang sukses atau sebagai modal simbolik, maupun mendapatkan otoritas dan pengakuan legitimasi sebagai pengusaha yang mampu menyediakan lapangan pekerjaan untuk para buruh batik.

\section{KESIMPULAN DAN SARAN}

\section{Kesimpulan}

Eksistensi batik Encim dalam arena produksi kultural dibedakan dalam dua arena yakni arena produksi terbatas dan arena produksi skala besar. Dalam arena produksi terbatas eksistensi batik Encim diperkuat dengan adanya konsistensi pengusaha dan seniman batik dari Cina Peranakan dengan berusaha menjaga kualitas batik Encim yang mencakup keindahan visual, aspek teknis pembuatannya, aspek fungsi kegunaanya sebagai penentu strata sosial masyarakat Cina Peranakan

Memasuki arena produksi skala besar, maka keunggulan-keunggalan tersebut mengalami penyerderhanaan karena mengikuti permintaan selera pasar batik Encim. Oleh karena itu, para pengusaha industri batik di Pekalongan memproduksi dan mereproduksi batik Encim dengan segala kreativitasnya. Kreativitas pemanfaatan teknologi dan teknik produksi batik baik: teknik tulis, cap, sablon malam, maupun printing, berdampak pada lahir inovasi bentuk produk-produk industri yang beraneka ragam.

Ranah industri batik menjadi arena untuk memperebutkan kekuasaan nilai batik Encim dengan didukung kepemilikan sumber daya modal. Pengusaha industri batik berupaya memiliki berbagai modal seperti: modal ekonomi, modal budaya, modal sosial, maupun modal simbolik untuk mendukung keberlangsungan dan menjadikannya sebagai kekuatan untuk bertahan dalam persaingan usaha batik pada era industri.

\section{Saran}

Batik Encim dapat diterima oleh para agen produksi kultural maupun konsumen produk kultural. Pemberian label nama batik dan penggunaan tanda tangan "Oey Soe Tjoen" memiliki daya kekuatan untuk menaikkan harga jual dari sebuah produk batik. Adanya praktik reproduksi dalam arena produksi kultural dengan cara memalsukan batik Oey Soe Tjoen, menjadi salah satu upaya pengusaha industri batik untuk mendapatkan keuntungan yang besar.

Hal tiru-meniru desain menjadi lumrah di kalangan pengusaha industri batik, karena banyak desain motif yang diciptakan tidak memiliki hak paten desain maupun hak merk produk. Oleh karena itu, kreator batik Encim dalam arena produksi terbatas perlu memiliki pemahaman dan kesadaran fungsi kekayaan intelektual, serta upaya nyata pendaftaran hak cipta desain maupun hak merk di direktorat jenderal hak kekayaan intelektual. Hal ini digunkan sebagai strategi perlindungan karya batik maupun desain-desain batik yang telah diciptakannya.

\section{DAFTAR RUJUKAN}

Amidjaja, N. T. (1966). Batik. Jakarta: Djambatan. Bourdieu, P. (2009). An Introduction to the Work of Pierre Bourdieu: The Practice Theory, (Habitus $x$ Modal $)+$ Ranah $=$ Praktik; Pengantar Paling Komprehensif kepada Pemikiran Bourdieu, Terjemahan Pipit Maizer. Yogyakarta: Jalasutra. 
(2015). The Field of Cultural

Production: Essay on Art and Literatur, Arena

Produksi Kultural: Sebuah Kajian Sosiologi

Budaya, Terjemahan Yudi Santosa. Yogyakarta:

Kreasi Wacana.

Djomena, N. S. (1990). Batik dan Mitra. Jakarta:

Djambatan.

Fashri, F. (2014). Pierre Bourdieu Menyingkap Kuasa Simbol. Yogyakarta: Jalasutra.

Ishwara, H., L. R.Yahya, \& Moeis, X. (2011). Batik

Pesisir Pusaka Indonesia, Koleksi Hartono

Sumarsono. Jakarta: KPG Kepustakaan Populer

Gramedia.

Miles, M. B., \& Huberman, A. M. (1992). Analisis

Data Kualitatif: Buku Sumber Tentang MetodeMetode Baru. Jakarta: UI Press.

Soedarso. (2006). Trilogi Seni: Penciptaan Eksistensi

Dan Kegunaan Seni. Yogyakarta: BP ISI

Yogyakarta.

Susanto, S. (1984). Seni dan Teknologi Kerajinan

Batik. Jakarta: Departemen Pendidikan dan

Kebudayaan, Direktorat Jenderal Pendidikan

Dasar dan Menengah, Direktorat Pendidikan

Menengah Kejuruan.

Wulandari, Tri. (2017). "Koleksi Museum Batik

Danar Hadi”. Hasil Dokumentasi Pribadi: 17

Desember 2017, Solo. 